\title{
„Sotva by koho mohl zajímati tuctový život úřednického synka, který bez velkých nesnází v slušném blahobytu vystudoval a stal se univerzitním profesorem.“ O Pamětech prof. JUDr. Jana Krčmáře
}

\author{
Dominik Macek
}

Právnická fakulta, Univerzita Karlova

Kontaktni e-mail:dominik.macek@centrum.cz

\begin{abstract}
"You could hardly think, that anyone would be interested in an ordinary life of a white-collar son, who finished his studies without any troubles along with considerable wealth and then went on to become a university professor."

Memoirs of prof. JUDr. Jan Krěmář
\end{abstract}

\begin{abstract}
:
The paper deals with the completely issued Memoirs of the university professor JUDr. Jan Krčmář, who has captured his childhood, the study of law, the career of a university dignitary, an academic, an official and a diplomat. The contribution should not only be a review of the published piece of work that contains a lot of notes as well, but also a humble guide to the extraordinary life of one of the most important personalities of the Czechoslovak civil law field.
\end{abstract}

\section{Keywords:}

Jan Krčmáŕ; civil law; Charles University; Faculty of Law; Czechoslovakia; Paris Peace Conference; Paris World Expo 1937

\section{Klíčová slova:}

Jan Krčmář; občanské právo; Univerzita Karlova; právnická fakulta; Československo; Pařížská mírová konference; Světová výstava v Paříži 1937

DOI: $10.14712 / 2464689 X .2019 .8$ 
Světlo světa spatřily kompletní Paměti univerzitního profesora JUDr. Jana Krčmáře (1877-1950), jejichž prvního dílu, ${ }^{1}$ který k vydání připravil Luboš Velek ve spolupráci s Alicí Velkovou a Martinem Klečackým, se čtenáři dočkali po celých deseti letech od vydání dílu druhého a třetího, ${ }^{2}$ které editovali Jana Čechurová a Jan Kuklík.

Jméno Jana Krčmáře, významného českého právníka první poloviny 20. století, svého času děkana pražské právnické fakulty a prvorepublikového ministra školství a národní osvěty, dodnes rezonuje v povědomí širší odborné veřejnosti. Jeho výborně čtivým jazykem psané memoáry, které svým vydáním prvního dílu připomněly 140 . výročí jeho narození, jsou př́ležitostí, jak si na jeho osobu a dílo vzpomenout.

\section{Krčmář pamětníkem}

V širší akademické veřejnosti je Krčmář coby velké jméno české civilistiky dobře znám, jeho bohatý a inspirativní život však jakoby byl již pozapomenut. V této souvislosti je nutno hned na začátku velmi příznivě ocenit úvodní medailony, ve kterých se editoři v obou knihách ve velké míře věnují Krčmářovu životu a dílu, čímž uvedou čtenáře do dobových a historických souvislostí a doplňují tak již vydané práce o jeho bohatém životě. ${ }^{3}$

Vzpomínky významných veřejných činitelů, paměti, nejsou v současnosti tolik frekventovaným žánrem. Objevují se memoáry umělců a politiků, vysokoškolských profesorů pak méně. Byt' Krčmáře jeho působením v čele prvorepublikového ministerstva v úřednických vládách lze jistě řadit i mezi veřejné činitele, v jeho dlouhém životě šlo o tak krátkou epizodu, že byl mnohem více přece jen pedagogem. V jeho vzpomínkovém díle, které sepsal v několika údobích mezi lety 1929 a 1940, pak můžeme vidět, s jakou precizností právníku vlastní vážil každého slova. Ze vzpomínání na jednotlivé členy rodiny, kolegy, studenty i přátele je cítit, s jakou pečlivostí kladl vzpomínky př́ijemné i nepř́ijemné, dobré i zlé na misky pomyslných vah, aby byl obraz co nejpřesnější. I přes tyto tisíce drobných rozhodnutí o každém slovíčku se předem omluvil, pokud by svým tvrzením snad komukoli uškodil. Vytkl však před závorku, že by tak pro svou vášnivou vůli k pravdě neučinil proti svému přesvědčení.

S nadsázkou lze říci, že to, čím byl pro Krčmářovu generaci fascikl vlastních vzpomínek, bude pro generaci soudobou kompletní datový soubor ze sociálních sítí. Netřeba posté žehrat, že takové útržky vzpomínek, byt' protkané fotografiemi a videi, uložené kdesi ve vzduchoprázdnu virtuální reality, nemohou konkurovat pečlivě psaným memoárům, jejich obrazným vyjádřením a vzletným souvětím. Nezbývá než věřit, že na cestu, kterou umetli svými knižně vydanými vzpomínkami takoví muži jako např́iklad Albín Bráf, Jaromír Čelakovský, Karel Mattuš, František Weyr nebo právě Jan Krčmář, se po jejich vzoru vydají i akademici současní, kteří tak zachytí své působení v proměnlivé a takříkajíc instantní době.

Krčmář pojal své dílo vskutku zeširoka, hned v úvodu vzpomíná na vlastní rodinu, a to až o tři generace nazpět. S jeho vlastními vzpomínkami se mísí dokonce odkazy

\footnotetext{
1 VELEK, L. (ed.). Jan Krčmář. Paměti, Díl I. Praha - Pelhřimov: Filozofická fakulta Univerzity Karlovy a Masarykův ústav a Archiv AV ČR a Nová tiskárna Pelhřimov, 2017.

2 ČECHUROVÁ, J. - KUKLÍK, J. (eds.). Jan Krčmár. Paměti, Díl II. Skoro státníkem. Díl III. Praha - Pelhřimov: Filozofická fakulta Univerzity Karlovy v Praze a Nová tiskárna Pelhřimov, 2007.

3 Srov. KUKLÍK, J. Profesor Jan Krčmář: pozapomenutá osobnost pražské civilistiky. Praha: Ediční stř̌edisko PF UK a Pražské sdružení Jednoty českých právníků, 2008.
} 
na literaturu, kde se o jeho př́buzných dá nalézt více, jelikož se mnozí z nich dostali do vzpomínek Jiráskových či prózy Novákové. Je nutno vést v patrnosti, že za podklad při samotném psaní autorovi nesloužily žádné deníky ani poznámky z jednotlivých let, toliko jeho vlastní pamět', která se jeví jako fenomenální. Právě jí vděčíme nejen za vyčerpávající a detailní informace o rodinném zázemí a dějinách rodu, ale i o všem dalším. Stran své paměti Krčmář sám píše, že po jednom přečtení „dokázal recitovati nejen báseň, nýbrž i hodný kus prózy“" ${ }^{4}$ na což jeho starší kolega a jeden z nejlepších přátel prof. JUDr. Josef Prušák podle vzpomínek ironicky odvětil, že ,,pamět’ není nikterak dokladem inteligence“' 5 Byt' tedy vinou nepoužívání deníkových podkladů či poznámek z popisovaných let se autor na mnoha místech zmýlil, zvláště v letopočtech či křestních jménech, ke cti editorů je třeba dodat, že tyto chyby odhalili a za pomocí jiných zdrojů uvedli na pravou míru. Krčmářova obsáhlá tvrzení jsou tak v poznámkách pod čarou konkretizována, doplněna a upřesněna a za tuto mravenčí práci fact checkerů patří editorům velký dík. Stejně tak za pečlivé a precizní vysvětlivky, kterými opatřili velké množství v textu užitých latinských výrazů a germanismů, jejichž význam zůstává dnešnímu čtenáři mnohdy skryt.

\section{Od žáčka k univerzitnímu profesorovi}

Rodinné zázemí a období dětství bylo pro Krčmáře, soudě podle rozsahu, v jakém se mu věnuje, vskutku určující. Četba Pamětí jistě nadchne každého, kdo se zajímá o každodenní život střední třídy v závěru 19. století. Krčmář popisuje města, kterými coby chlapec s rodinou, která následovala otce do míst jeho služebního určení, prošel. Do detailu vzpomíná na školní léta, nevynechává vzpomínky na spolužáky neznámé i známé, jako např. na pozdějšího děkana pražské právnické fakulty a rektora Univerzity Karlovy prof. JUDr. Josefa Drachovského, kterého při vzpomínce na studia na plzeňském reálném gymnáziu líčí jako „obtloustlého chlapíčka, velmi horlivého v učení, velmi učenlivého a navýsost slušného“. 6 Své místo si zasloužila také studentská léta na pražském gymnáziu v Žitné ulici, kde mezi Krčmářovy středoškolské profesory patřili takoví muži jako Alois Jirásek či Jiří Guth-Jarkovský. Nespornou přidanou hodnotou Krčmářových vzpomínek jsou stovky, ba př́mo tisíce drobných stř́pků zajímavostí, poznámek a noticek z jeho bohatého života. Ve kterém z jiných děl bychom se dočetli, že spolužáku Krčmáře (zvaného mezi gymnazisty Krčma), pozdějšímu egyptologu prof. PhDr. Františku Lexovi se během studentských let říkalo pro jeho ,štětinaté vlasy a štětinaté chování“7 Dikobraz, a ,pro zálibu v matematice, fyzice a chemii se také někdy jmenoval Lexičitan uhličitý'“? ${ }^{8}$ Svá vyprávění o letech stř̌edoškolských Krčmář ukončuje nejen popisem období, kdy prožíval proces s Omladinou, který jeho otec coby předseda senátu vedl, nýbrž také poetickými slovy o tom, proč ve vzpomínkách věnovaným mladickým létům nehovoří o ženách: „Kdyby o těch věcech mělo býti psáno všechno nebo aspoň všechno podstatné, bylo by v tom leccos nevkusného, a kdyby se podstatné kusy vynechaly, bylo by to nepravdivé a zkreslené. “9 Nesestoupil

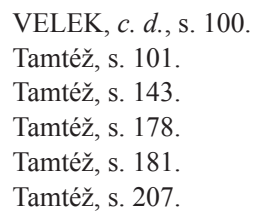


snad po takových upřímných slovech velký muž českého právnického nebe z piedestalu a nestal se čtenáři lidsky bližším a opravdovějším?

Své obšírné vyprávění věnuje Krčmář pražské české právnické fakultě, na kterou nastoupil roku 1895 jako student a pokračoval zde i ve své pedagogické činnosti. Bez nadsázky se dá říci, že se jedná o kroniku právnické fakulty sui generis, kdy jeho fenomenální pamět' uchovala nejen poznatky o běžném chodu instituce, ale také mnohé zábavné př́běhy či znamenité detaily o životě studentů i pedagogů. Široký prostor při líčení svého působení na fakultě věnuje osobním vzpomínkám na své učitele a kolegy - univerzitní profesory, namátkou na proslulého Antonína rytíře Randu, respektovaného Emila Otta, poutavého Josefa Stupeckého, ušlechtilého Františka Storcha či zábavného Albína Bráfa. ${ }^{10}$

Jako poutavým cestopisem, jako velkým příběhem prochází čtenář při vzpomínkách na studijní pobyt v Lipsku, na habilitaci, mimořádnou i řádnou profesuru i výkon funkce ředitele univerzitní kanceláře. Vyrovnává se s úmrtími blízkých kolegů, které takřka paralyzovaly civilistickou část právnické fakulty, kdy Krčmář byl jediným zástupcem občanského práva na české právnické fakultě po dobu deseti let. ${ }^{11}$ Při svých vzpomínkách nezapomíná na svou vášeň sběratelskou, široce referuje o pražských uměleckých jednotách, kterých byl členem, nezapomíná na svou vášeň cestovatelskou, popisuje své cesty po světě i vlasti, kde nejednu z takových cest podnikl společně se svými fakultními kolegy. Těmto cestám učinila přestávku první světová válka, o níž se také Krčmář - kupodivu velmi stručně - zmiňuje. Vyhlášením samostatného Československa je pak první díl jeho velkých Pamětí dovršen.

Kdo by po přečtení prvního dílu měl pocit, že toho Krčmář zažil tolik, jako jiný nezažije za celý život, zřejmě by nebyl daleko pravdy. ${ }^{12}$ Vždyt' jsme jej viděli u činnosti studijní, vědecké, pedagogické, úřednické, akademické a snad trochu i cestovatelské. Je třeba si však uvědomit, že v osmnáctém roce bylo Krčmářovi jednačtyřicet let, byl na vrcholu svých sil a mnohé měl stále před sebou. Stejně tak jako první díl pojednává bohatě o životě střední třídy v posledních desetiletích existence rakousko-uherské monarchie, druhý díl je nesporně bohatým pramenem pro výzkum československé státnosti, jejího vzniku a role státotvorné elity v ní. ${ }^{13}$

\section{Krčmář skoro státníkem}

Rok 1918 znamenal také pro Krčmáře životní předěl, nedlouho po něm se stal, jak napovídá název druhého dílu, ,skoro státníkem“. ${ }^{14}$ Pro své znalosti v civilním právu, stejně tak mezinárodním právu soukromém a zálibě v historické právní vědě, byl záhy po vzniku

10 Užitá adjektiva jsou Krčmářova. VELEK, c. d., s. 230.

11 VELEK, c. d., s. 334.

12 Srov. ČECHUROVÁ, J. - KUKLÍK, J. Nenápadný profesor, který byl snad u všeho - Paměti Jana Krčmáře. In: SEKYRKOVÁ, M. (ed.). Paméti a vzpomínky jako historický pramen. Práce z dějin techniky a př́rodních věd. Praha: Národní technické muzeum, 2006, s. 157-166.

13 Srov. ČECHUROVÁ, J. - KUKLÍK, J. Paměti Jana Krčmáře. Dosud nevyužitý pramen k dějinám československé státnosti (a zdaleka nejen k nim). In: MALÝ, K. - SOUKUP, L. (eds.). Vývoj české ústavnosti v letech 1618-1918. Praha: Nakladatelství Karolinum, 2007, s. 782-789.

14 Srov. VELEK, L. Převrat prof. Jana Krčmáře. In: KUČERA, R. (ed.). Muži řijna 1918: osudy aktérů vzniku Republiky československé. Praha: Masarykův ústav a Archiv Akademie věd ČR, 2011, s. 131-143. 
ČSR vybrán coby právní expert pro čs. delegaci na mírové konferenci v Paříži, ${ }^{15}$ na které pracoval na významných otázkách, např́klad na otázce válečných reparací či osudu Hlučínska. Během své pařížské činnosti stačil ještě také ve funkci experta Národního shromáždění, ve které vystřídal kolegu prof. JUDr. Emila Svobodu, radit v otázkách připravované pozemkové reformy, do jejíchž dějin se zapsal nejen jako ten, který pro tzv. záborový zákon ,vynašel pojem záboru“. ${ }^{16}$ Jeho rady si vyžádali také předkladatelé známé tzv. manželské novely, která byla beze všech pochybností nejvýznamnějším prvorepublikovým zásahem do rodinného práva. Tato novela změnila dosavadní úpravu manželství obsaženou v recipovaném ABGB a sjednotila otázky sňatku v českých zemích i na Slovensku. Na území Slovenska totiž na rozdíl od české a moravskoslezské části ČSR již za dob rakousko-uherských platila jako jediná prŕípustná forma sňatku forma občanská, novela však přinesla možnost svobodně si vybrat mezi občanským a církevním sňatkem, a to na celém území republiky. Krčmář vzpomíná také na iniciativu navrácení především rudolfinských uměleckých památek z vídeňských sbírek zpět do Prahy, kterou prosazoval i známý prof. V. V. Štech, a to po vzoru Belgičanů, miláčků mírové konference, kteří se obdobné ustanovení pokoušeli též do mírových smluv prosadit. V obsáhlých vývodech o svém pařížském působení nezapomíná na velmi delikátní otázku minoritní, a to právě ve vztahu k menšině německé, mad'arské a polské. Právě velké spory s Polskem o osud Těšínska, které bylo stran uhelných ložisek a průmyslu a pro košicko-bohumínskou dráhu pro nový stát klíčové, Krčmáře vedly k nápadu prosadit pro slezskou Karvinou s výraznou polskou menšinou autonomní statut. I pro tyto drobné, přesto významné ideje jsou Paměti dosud nedoceněným pramenem (nejen) ke vzniku Československa.

Po mírové konferenci byl dále činný in publicis et politici ${ }^{17}$ coby expert pro nejedno ministerstvo, ${ }^{18}$ též hájil čs. zájmy před Stálým dvorem mezinárodní spravedlnosti v Haagu ve sporu s Polskem o spišskou obec Javorina, o kterém se jakožto o mezinárodním sporu, který se stal otázkou prestiže obou států, zmiňuje velmi zevrubně. Svým expertním hlasem erudovaného právníka byl Krčmář nablízku jednáním týkajícím se nakonec nepřijatého Ženevského protokolu, stejně tak pozdějším jednáním locarnským. Jelikož sám dokonce dvakrát působil coby ministr školství a národní osvěty v československých vládách, nenechal ani toto „vládní“ období bez povšimnutí. Se vší skromností podotýká, že spolu s kolegy v úřrednické vládě zemi skutečně nevládli, nýbrž ji spravovali. ${ }^{19} \mathrm{O}$ sobě pak dodává, že každému povolání je třeba se nejprve naučit. A přestože řemeslu ministerskému jej nikdo neučil, přesto se jím stal. V této souvislosti vtipně parafrázuje výrok mladé Vesaniové z Casanovových pamětí, která se ptala: „Což pak se lze státi operní tanečnicí beze vší př́pravy jako ministerským předsedou? “20 Jak už bylo několikrát explicitně či mezi řádky zmíněno, i se svým ministerským působením se Krčmář vyrovnal s podrobností sobě

15 Srov. KUKLÍK, J. Československá delegace na pařǐžské mírové konferenci ve světle memoárů profesora Jana Krčmáře. In: Zrod nové Evropy: Versailles, St-Germain, Trianon a dotváření poválečného mírového systému. Praha: Historický ústav, 2011, s. 126-138.

16 ČECHUROVÁ - KUKLÍK (eds.). Jan Krčmář. Paměti, Díl II. Skoro státníkem. Díl III., s. 31.

17 In publicis et politici (lat.) = ve veřejném a politickém životě.

18 Srov. ČECHUROVÁ, J. Cestování ve službách československé diplomacie (očima prof. Jana Krčmáře). In: ŠTEMBERK, J. - MANOVÁ, M. Historie a cestovni ruch-perspektivní a podnětné spojeni. Pocta profesoru Vratislavu Čapkovi k 85. narozeninám. Praha: Vysoká škola obchodní v Praze, 2008, s. 265-275.

19 První Krčmářův pobyt v čele ministerstva trval od 18. března 1926 do 12. ř́ijna t. r.

20 ČECHUROVÁ - KUKLÍK (eds.). Jan Krčmár. Paměti, Díl II. Skoro státníkem. Díl III., s. 142. 
vlastní a dal nám nahlédnout pod pokličku fungování ministerstva v polovině dvacátých let minulého století. Je nutné zmínit, že ačkoli Krčmář odvedl v úřadu dobrou práci jak podle mínění ministerského úřrednictva, tak podle mínění předsedy vlády, ne všichni ji vnímali takto kladně. V poslední větě věnované prvnímu ministerskému působení si mezi řečí postěžoval, že na právnické fakultě ,,ani mne v prvé schůzi sboru, které jsem se účastnil, děkan (prof. JUDr. Jiří Hoetzl, pozn. aut.) nepřivítal, ačkoli (to) bývá zvykem... Z toho i jiných důvodů jsem měl dojem, že moji nejbližší kolegové neměli valné radosti, že jeden z jejich středu zastával nejvyšší školský úřad republiky.“21

Krčmář se stal během svého druhého ministerského působení v letech třicátých ${ }^{22}$ svědkem ožehavého provádění legis Marešs, ${ }^{23}$ ve kterém, byt’ byl stále profesorem české univerzity, sehrál coby resortní ministr smírčí úlohu prostředníka. Obšírně popisuje napětí mezi hodnostáři obou univerzit, jejichž animozita byla tak velká, že k předání insignií muselo dojít právě skrze ministerskou komisi, která je převzala na rektorátu německé univerzity, a Krčmář je v ministerstvu postoupil rektoru české univerzity Drachovskému, který dorazil společně s prof. Karlem Dominem a děkany fakult. Z této události pramení Krčmářem popsaná roztržka mezi rektorem Drachovským a předsedou vlády Malypetrem, kterému Drachovský slíbil, že předání insignií proběhne bez účasti studentů, oficialit a oslav. Po převzetí však navzdory slibu v budově české právnické fakulty, kde sídlil i rektorát, došlo k velkým oslavám, kterým byl podle vzpomínek přítomen i navrhovatel zákona prof. František Mareš, který se spolu s Drachovským a Dominem navzájem věnčil nabytým rektorským řetězem. ${ }^{24}$

Do let jeho druhého ministerského působení spadají obsáhlé statě o pražské kulturní scéně na prknech Národního divadla, kdy měl Zlatou kapličku ve své gesci. Můžeme se tak prostřednictvím vynikajícího pozorovatele setkat s takovými jmény jako Olga Scheinpflugová, Jiřina Šejbalová, Jan Werich a Jiří Voskovec nebo Václav Vydra starší. Není bez zajímavosti, že obraz Albrechta Dürera Růžencová slavnost, který dodnes můžeme obdivovat v Národní galerii coby jeden z jejích obrazů nejcennějších, byl od Strahovského kláštera státem zakoupen za tehdy závratných 18 milionů korun za dob druhého ministrování Jana Krčmáře, který měl nákup v kompetenci. Tento nákup hájil navzdory panující hospodářské krizi a byl ve svém postoji silně podpořen Edvardem Benešem. Právě ministerskou demisí z 23. ledna 1936 ukončil Krčmář o tři roky později psaní druhého dílu svých Pamětí.

Při vzpomínání na nespočet aktivit, kterým se Krčmář po založení republiky věnoval, od Pařŕže přes Locarno až na pražské ministerstvo, není divu, že na akademické působení nezbývalo tolik času, kolik by si býval přál. Sám deklaruje, že se fakultě odcizil zvlášt' po stránce osobní, staří kolegové byli penzionováni nebo již nežili, mladé kvůli všem svým aktivitám mimo fakultu takř́ikajíc neznal. Jeho poznámky o fakultním životě po roce 1918 tedy již tak bohaté nejsou, snad právě pro velkou šiŕi jiných aktivit v meziválečném období

21 ČECHUROVÁ - KUKLÍK (eds.). Jan Krčmářr. Paměti, Díl II. Skoro státníkem. Díl III., s. 169.

22 Podruhé stál Krčmář v čele téhož ministerstva od 14. února 1934 do 23. ledna 1936, a to celkem ve třech vládách - druhé a třetí vládě Jana Malypetra a v první vládě Milana Hodži.

23 Zákon č. 135/1920 Sb. z. a n. zvaný podle svého navrhovatele, rektora Univerzity Karlovy prof. MUDr. Františka Mareše, přiznal pouze české univerzitě právo nést přídomek Karlova a považovat se tím za pokračovatelku univerzity založené Karlem IV., zároveň řešil též problematiku dělení univerzitního majetku a univerzitních insignií.

24 ČECHUROVÁ - KUKLÍK (eds.). Jan Krčmářr. Paměti, Díl II. Skoro státníkem. Díl III., s. 186. 
své fakultní působení z paměti, byt' vynikající, jaksi vytěsnil. Sám si toho byl vědom a otevřeně poznamenal, že napsat o „dvaceti létech života v hlavním povolání několik málo desítek stran, zdá se mně žalostně málo“.

Stejně jako v prvním díle najdeme i v tom třetím mnohé unikátní perličky a střípky z fakultního provozu. Namátkou lze zmínit volbu děkana v ak. roce 1922/1923, kdy se proti prof. JUDr. Antonínu Hobzovi postavil prof. JUDr. Karel Hermann-Otavský, nejstarší z bývalých děkanů, kterého podporoval dosavadní děkan Vilém Funk se slovy, že se „Hobza na mírové konferenci v Paříži nažral již dost a měl by rok počkati. "25 Zvolen byl skutečně Hermann-Otavský a neúspěšný kandidát Hobza si ve věci volby stěžoval až u ministra školství a národní osvěty, přičemž argumentoval zásadami morálními a nikoli právními. Celý rok se pak ve sboru nesl ve znamení slovních přestřelek a dusné atmosféry, který vyvrcholil ostentativním odchodem pánů s Hobzou spřízněných ze schůze. Právě od té doby, jak Krčmář píše, spolu on a Hobza již více nepromluvili. Rozepř́ mezi esy čs. právní vědy bylo povícero, na několika stranách může čtenář nahlédnout do sporu a korespondence mezi Krčmářem a brněnským prof. JUDr. Jaromírem Sedláčkem, který spustil Sedláčkem psaný ne zcela tradiční příspěvek ke Krčmářovým šedesátinám.

Po svém odchodu z vlády po naléhání prrijal nabídku stát se čs. generálním komisařem na Světové výstavě v Paříži roku 1937.26 Šlo o poslední velké veřejné angažmá v Krčmářově životě, přesto byla tato funkce podle jeho vzpomínek vskutku darem danajským. Najít shodu mezi především finančními zájmy vícer ministerstev, hodnostářů, porotců, architektů a sochařu bylo nadlidským úkolem. Ani jeho léty prověřené schopnosti právní, organizační a administrativní nestačily $\mathrm{k}$ bezproblémovému provedení náročného úkolu, který mu byl uložen. Útoky, které se nesly ze všech stran, velmi často zcela nepodložené, nesl velmi těžce a z př́slušné kapitoly, nikterak krátké, je cítit nejen jeho frustrace, ale také potřeba očistit se od špíny, která na něm v souvislosti se Světovou výstavou neoprávněně ulpěla. Kývnutí na nabídku stát se generálním komisařem trpce litoval.

Z jeho dalších významných aktivit nelze nezmínit jeho práci na osnově meziválečného občanského zákoníku, na které se velkou měrou podílel, stejně tak bohatou činnost tvưrčí, kdy vydal jako první učebnice občanského práva, které byly pro svou úroveň vysoce ceněné. ${ }^{27}$ Přehlédneme-li jeho bohatou činnost za první čs. republiky, nejde než dát za pravdu jeho slovům, že se „účastnil mnohých vážných a zajímavých věcí a snad svým účastenstvím leckdy zájmům státu i trochu prospěl“".28

V závěru jeho vzpomínek se dostalo také na věci takříkajíc soukromé. Jeho velkou zálibou bylo již zmíněné výtvarné umění a sběratelství, coby předseda Společnosti vlasteneckých přátel umění v Čechách se stýkal s takovými mistry, jakými byli Rudolf Kremlička nebo z díla Oty Pavla známý Vratislav Nechleba. Dostalo se však i na další z jeho soukromých aktivit, od zájmů typu divadla a filmu, až po jeho sňatek s herečkou a malíŕkou Mílou Pačovou, která jej uvedla mezi další známé tváře prvorepublikového kulturního

25 ČECHUROVÁ - KUKLÍK (eds.). Jan Krčmář. Paměti, Díl II. Skoro státníkem. Díl III., s. 224.

26 Srov. ČECHUROVÁ, J. - KUKLÍK, J. Z utrpení československého generálního komisaře. Prof. Jan Krčmář a Světová výstava v Paříži roku 1937. In: Svět historie-Historikův svět. Sbornik profesoru Robertu Kvačkovi. Liberec: Technická univerzita v Liberci, 2007, s. 371-394.

27 KRČMÁR̆, J. Právo občanské, I.-V. Praha: Spolek československých právníků Všehrd, 1929-1930.

28 ČECHUROVÁ - KUKLÍK (eds.). Jan Krčmář. Paměti, Díl II. Skoro státníkem. Díl III., s. 46. 
života. Několik stránek o sídle Krčmářových v Třemošnici a návštěvách v něm uzavírá dobrodružnou cestu vzpomínkami velkého českého právníka.

\section{Závěr}

Čeho může čtenář jen tiše litovat je, že se Krčmář ve svých memoárech nedostal něco málo přes deset let dále. Nebylo by jistě bez zajímavosti si přečíst, jak snášel dobu válečnou a následný zákaz přednášet na právnické fakultě, kterému se mu dostalo po únorových událostech roku 1948. Zákaz vykonávání akademické činnosti jej zastihl už podruhé v kariéře, poprvé nuceně přerušil svou kariéru vysokoškolského pedagoga spolu s ostatními po zavření vysokých škol r. 1939. Tento první zákaz paradoxně přispěl k tomu, že měl Krčmář dostatek času zkompletovat své paměti. Neméně zajímavý by byl jeho osobní pohled na příspěvek k tvorbě tzv. Středního kodexu, tj. občanského zákoníku z roku 1950, do jehož kodifikační komise byl vedle dělníků z pražských továren přizván také a kde zanechal svou poslední stopu. Necelých pět měsíců před jeho schválením totiž v nedožitých třiasedmdesáti letech Jan Krčmář zemřel.

Suma sumárum, jen v prvním díle Pamětí je na sedmnáct stovek poznámek pod čarou, ve vydání druhého a třetího dílu pak přes osm stovek. Jedná se o již zmíněnou precizní práci editorů, kteří podrobili svému zkoumání sebedrobnější Krčmářovu poznámku, která si zasloužila vysvětlivku pro dnešního čtenáře, popř. odkazy na jiná díla. Je škoda, že se oproti původnímu záměru vydat všechny díly Pamětí zároveň a jedním editorským týmem čtenáři dočkali prvního dílu až po deseti letech od vydání druhého a třetího, který nakonec vyšel péčí odlišného editorského týmu. Přesto je třeba kvitovat, že nezůstal dříve vydaný díl torzem a došlo, byt' se zpožděním, k úplnému vydání Pamětí. Lehce kriticky je třeba nahlížet na grafické zpracování přebalu, který by zasloužil větší péči ze strany svého autora. Takto se duchem velké memoáry významného muže v knihovně lehce ztratí v záplavě nevýrazných přebalů, kterými knižní trh oplývá ve velkém. Kdo však i přes tento nedostatek po Pamětech sáhne, jak z výše uvedeného plyne, nejenže nebude chybovat, ale obohatí se o nespočet nových a unikátních poznatků ze života české společnosti, univerzity, monarchie i republiky. Byt' tedy sám autor v předmluvě svého opusu pochybuje, že „by [sotva] koho mohl zajímati tuctový život úřednického synka, který bez velkých nesnází v slušném blahobytu vystudoval a stal se univerzitním profesorem“, opak je pravdou. Život tohoto úřednického synka je dodnes životem pozoruhodným. 